\title{
CUSTOMS OF THE AWUNA TRIBES
}

I HAD been out shooting one afternoon and was trudging wearily along a footpath through the belt of loose sand that extends for some miles from the sea in that part of the Gold Coast where $I$ am at present stationed, when, nearing the village of We, I heard the sound of weird, demoniacal laughter coming from a chorus of voices that rose above the monotonous rumbling noise of a native band of drums and rattles.

Wondering what could be the nature of the mirth that expressed itself in so remarkable a manner, I followed the sound, and threading my way through pigs and naked children that were roaming about the village with that thorough confidence in one another which is born of long companionship, came to an open square in front of the Fetish Priest's house where a sacred dance was in full swing.

About thirty women of ages varying from sixteen to sixty were energetically performing the strangest dance that it has ever been my lot to witness. They were clothed, from the waist to the knee, in the folds of a bright-coloured cloth, their hair screwed into all kinds of fantastic shapes and adorned in front with an erect row of scarlet birds' feathers, a heavy necklace of beads hung from the shoulder to the opposite hip and their faces grotesquely contorted to represent the angry mood of the dread being Hebieso-the God of Thunder.

Round and round the circle formed by the onlookers these women rushed, moving their arms backwards-until the elbows nearly met behind their backs-and forwards in time with the movement of their feet; writhing and wriggling their bodies the while. At intervals the musicians would quicken their time and the dance rose to a perfect frenzy; the 
dancers giving out the peculiar yell that I have mentioned before, some of them racing round on their hands and feet, others clinging to the boughs of a tree that grew in the centre of the square and performing monkey-like antics. Terribly in earnest they were, the perspiration streaming from them until some, utterly exhausted, rushed into the Fetish house, their place being immediately taken by others who had been resting there.

One woman-the heroine of the play-especially attracted my attention. Her head was shaved perfectly clean the better, it seemed, to display a slight wound which she had lately received as the result of a temporary revolt from the authority of her lord and master. Now this good man might have given his spouse a sound thrashing with impunity had he only left her head intact. As it was, his rash act recoiled on himself with tenfold force.

Among the Hebieso-worshippers the human head is connected, in some unexplainable way, with the presence of the protective spirit of their God-Hebieso-which has been passed into them, through this channel, at the ceremony of baptism. Any injury to this sacred member is therefore carefully guarded against, as a wound-of sufficiently grave a nature to draw blood-is believed to result in loss of reason to the smitten one. The person inflicting the wound brings down on himself the thunders of the wrath of Hebieso and of his mouthpiece the Fetish priest.

Now our heroine had studied well the articles of her faith and knew what her traditions expected of her. She seems to have acted her part very well, for immediately on receiving her broken head she rushed screaming away from the village to the bush evincing all the signs of incipient madness.

Then there was a tremendous hubbub. All the relatives consulted the Fetish Priest; the unfortunate husband was sought out and made to understand that unless he obtained the professional assistance of the Priest in removing, by means of the Fetish, the curse that he had put on his wife, things would be made hot for him, in fact, he himself would be put under Fetish.

Of course, no African is hardy enough to hold out under 
such a threat as this, so he promptly and tremblingly came to terms.

The Priest then turned out the Fetish girls of his household, who duly proceeded to find the escaped lunatic-not a very difficult matter seeing that she was just on the outskirts of the village patiently waiting to be found. She was led back with great ceremony and the dance which I have described with its attendant rites was all part and parcel of the prescription ordered by the Fetish Priest for bringing back the demented woman to her normal sanity as well as for re-establishing her bad-tempered and violent husband in the good graces of the Hebieso.

I need hardly say that the unhappy man had to provide all the refreshments consumed during this ceremony, (which lasted three days), and pay the fetish priest for his professional services.

Harry france. 